\title{
Comparison of Building Structure Planning with SNI 2847-2013 Method and SAP2000 V.19 Software Code ACI 318-14
}

\author{
Ada Bina Avizan \\ Civil Engineering Study Program \\ Narotama University Surabaya \\ Arif Rahman Hakim 51 Street, Sukolilo, Surabaya \\ adabina80@gmail.com \\ Koespiadi \\ koespiadi@narotama.ac.id \\ Civil Engineering Study Program \\ Narotama University Surabaya \\ Arif Rahman Hakim 51 Street, Sukolilo, Surabaya
}

\begin{abstract}
ABSTRAK
Building construction planning in Indonesia uses SNI 2847: 2013 regulatory guidelines especially in building planning. So we need a combination of standardization used with technological developments that are realized in a computer program to simplify and speed up calculations. The results of the calculation of beam structures and concrete columns in the final project calculations using SNI 2847: 2013 regulations and analysis using SAP2000 code ACl318-14 software obtained the results: a) In plimelinary beam designs with sizes B1 30/40 cm and B2 40/55 cm are not able hold the load on the structure (over strange), then the beam dimensions are enlarged to $B 130 / 60 \mathrm{~cm}$ and B2 $40 / 60 \mathrm{~cm}$. In the SAP2000 output analysis results after the beam dimensions are enlarged there are no over strange frames and meet the strength of the structure. b) From the beam analysis planning on bending reinforcement using SNI 03-2847-2013 concrete reinforcement regulations and using SAP2000 code ACI318-14 software analysis, the number of reinforcement obtained is more using SNI 03-2847-2013 concrete reinforcement regulations compared to using software analysis SAP2000 code ACl318-14 the amount of reinforcement used has a difference of $0.17 \%$. c). From the planning of column analysis on bending reinforcement using SNI 03-2847-2013 concrete reinforcement regulations and using SAP2000 code ACl318-14 software analysis, the same amount of reinforcement is obtained between calculations using SNI 03-2847-2013 concrete reinforcement regulations and using SAP2000 code ACl318 software analysis -14 .
\end{abstract}

Keyword : SAP 2000, SNI 2847-2013, SNI 1726-2012,Beam,Coloumn

\section{INTRODUCTION}

Analysis and design of the structure experienced significant development with the development of structural analysis and design software. An increase which is very influential with the existence of structural analysis software is a matter of productivity in structural analysis and design. Before the existence of structural analysis software to do the analysis and design of multi-storey building structures will require a long time and result in the project planning process being delayed, with the software the analysis and design can be done quickly, so that it can streamline the planning time of a project. In planning the construction of buildings in Indonesia use the SNI 2847: 2013 regulatory guidelines, especially those involving concrete work. This procedure includes general requirements as well as technical provisions for planning and implementing concrete structures for buildings or other structures that have similar characteristics to building structures.

Computer programs are made to simplify and speed up calculations when compared to conventional methods, namely with a manual calculation calculator. Analysis of reinforced concrete structures will be easier with the application of programming languages with SAP2000 software. The output of this software is in the 
form of adequate dimensions, number and diameter of the longitudinal reinforcement and shear reinforcement, and the output forces. This application also provides benefits for planners because it is easier and more efficient. The results of this SAP2000 software output are the number and diameter of the longitudinal reinforcement and the shear reinforcement only in the beam and column structure, therefore this study only reviews the beam and column structure. This study aims to determine the comparison of building structure planning results using SNI 2847-2013 guidelines using SAP2000 V.19 software, especially in portal structures (beams and columns). Based on the background description above, the research problem formulation is as follows: 1) How is the modeling of building structure planning using SAP2000 V.19 software?, 2) How do the comparison of building structure planning results using SNI 2847-2013 guidelines using SAP2000 V.19 software especially in beam structures ?, 3) How do the comparison of building structure planning results using the SNI 2847-2013 guidelines using SAP2000 V.19 software especially in column structures

The beam is one of the building structural elements whose main function is to accept bending and sliding loads, but not for axial forces. How to determine a structural element as a block we can do by clicking: "Define -> Frame Section -> Add New Property $\rightarrow$ Concrete $\rightarrow$ Rectangular.

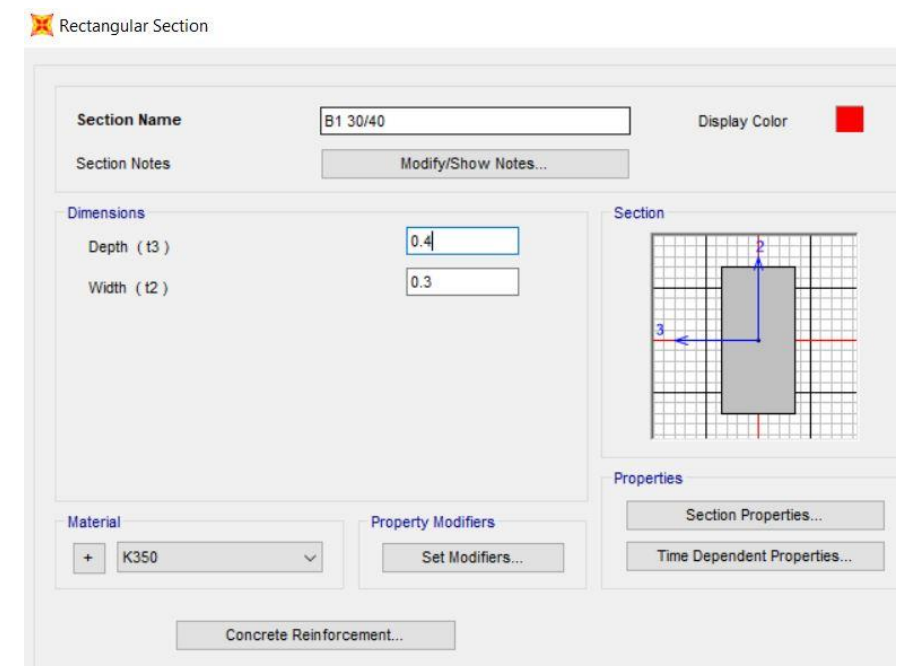

Gambar 1. Modeling beam dimensions using SAP2000 software

\section{Column Planning Concept Using SNI 2847-2013}

The columns in a building function as supporting loads from beams and plates, to be transmitted to the subgrade through the foundation. The load from the beam and plate is compressive axial load and bending moment. According to SNI 03-2847-2013, columns must be designed to withstand the axial force from the factor load on all floors or roofs and maximum moments. Loading conditions that provide the maximum moment ratio to axial load must also be reviewed. The stages in analyzing columns: 1) Reinforcement for columns is made symmetrical reinforcement based on a combination of $\mathrm{Pu}$ and $\mathrm{Mu}, 2$ ) Maximum column design load, 3) maximum column design moment for upper and lower end, 4) Value of fixed contribution to deformation, 5 ) Modulus of Elasticity, 6) The value of column and beam sensitivity, 7) Eccentricity Value, 8) Determine $\Psi_{\mathrm{a}}$ and $\left.\Psi \mathrm{b}, 9\right)$ The value of column slenderness, 10) Magnification of moments, 11) Reinforcement design, 12) Determine the reinforcement used, 13) Check $\mathrm{Pu}$ against balanced load, 14) Checking cross-sectional strength, 15) Shear Reinforcement. 


\section{Column Planning Concept Using SAP2000 Sofware}

Column is one of the structural elements of a building whose main function is to receive axial loads. How to determine a structural element as a column we can do by clicking: "Define -> Frame Section -> Add New Property -> Concrete -> Rectangular (for concrete with a square cross section)".

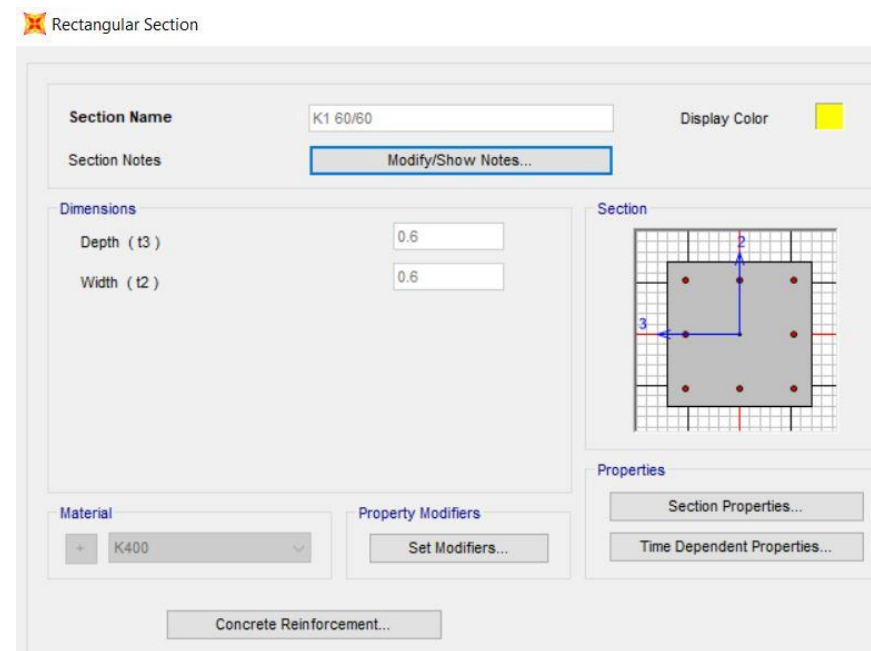

Gambar 2. Modeling column dimensions using SAP2000 software

\section{RESEARCH METHODOLOGY}

\section{Research Flowchart}

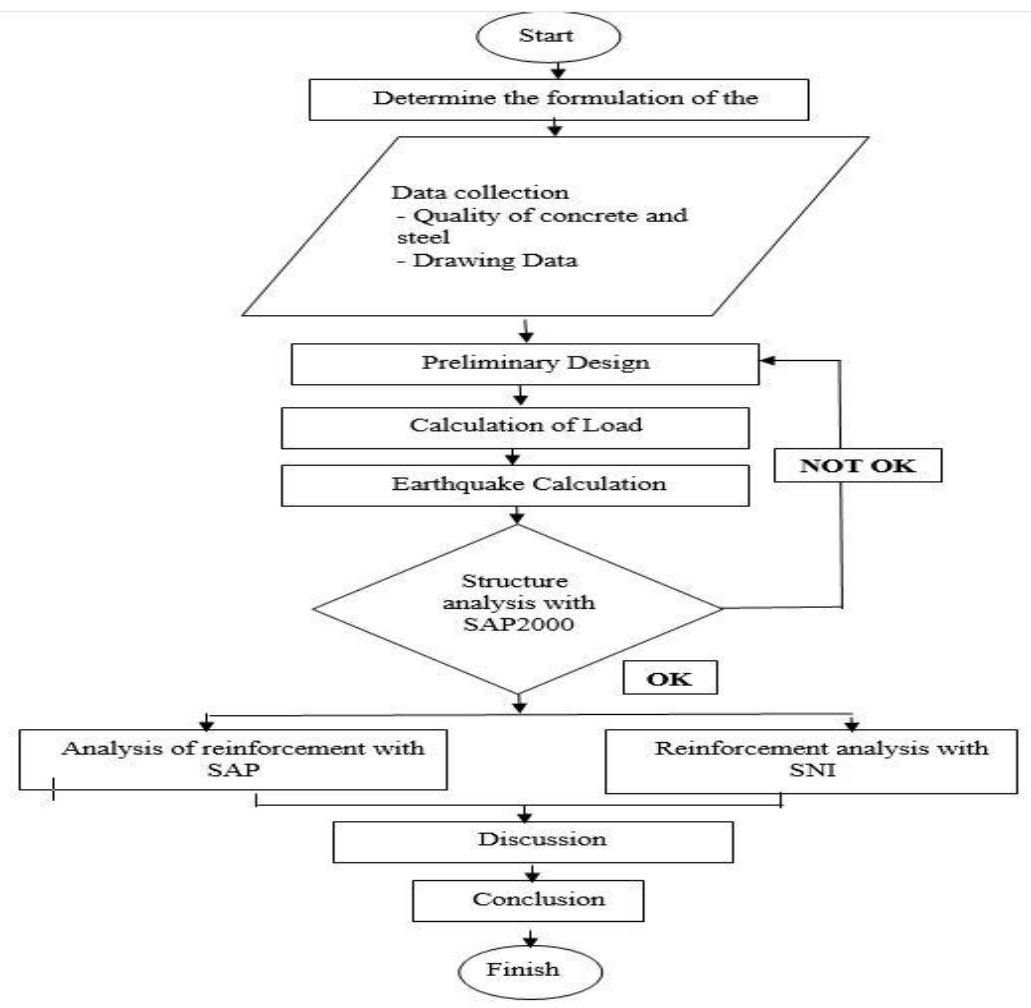

Gambar3.Research Flowchart 


\section{Data Collection Technique}

The data needed in the preparation of the final project with the title "Comparison of Building Structure Planning Using SNI 2847-2013 and SAP2000 V.19 Software include: 1) Architectural drawing data, 2) Structure drawing data, 3) Material data.

\section{DataProcessing}

Comparative analysis of building structure planning using SNI 2847-2013 and SAP200 V.19 Software must have primary and secondary data to be compared so as to find differences in the results of the analysis. 1) Collection of literature, 2) Selection of material to be used, 3) Design of beam and column dimensions, 4) Application of planning using SNI 2847-2013 on beam and column structure, 5) Application of planning using SAP2000 on beam and column structure.

\section{Literatur Research}

In the preparation of this thesis there are a number of building regulations that become guidelines, including: 1) Procedures for calculating concrete structures for buildings SNI 2847-2013, 2) Earthquake resistance planning standards for building structures SNI 1726-2012, 3) Indonesian loading regulations for buildings and other buildings SNI 1727-2013.

\section{Data Analysis}

Structural analysis using SAP2000 V.19 software to run the SAP2000 V.19 program structural modeling was performed. The output of the SAP2000 V.19 program is used to design reinforcement of beams and columns with SNI 2847-2013 guidelines which will be compared with the results of the analysis of the SAP2000 V.19 program code ACI 318-14.

\section{Discussion Of Results}

From the analysis results obtained the number of reinforcement in structural components (beams, columns) SNI 2847: 2013 regulations on structural concrete requirements for buildings and the results of analysis of SAP2000 V.19 software code $\mathrm{ACl}$ 318-14 then comparing the number of reinforcement can be drawn conclusions and suggestions .

\section{RESULT AND DISCUSSION}

\section{General}

Preliminary design is the initial step used to plan the dimensions of the structure of the building, the structure and structural components are planned so that all cross sections have a minimum plan strength equal to the strength needed to be calculated based on a combination of load and factored force in accordance with the arrangement.

\section{Planning data}

1. Bulding Type : Hotel

2. High Building $: 32,5 \mathrm{~m}$

3. Earthquake zone : Madiun

4. Type of Soil : Medium Land

5. Concrete Quality (K) : K300 (Plate, Shearwall)

: K350 (Beam)

: K400 (Column)

Steel Quality $\quad$ : BJTP U24 fy $240 \mathrm{Mpa}$

Building Structure : : Reinforced Concrate 


\section{Preliminary Beam Design}

Table 1. Recapitulation of beam dimensions

\begin{tabular}{ccccc}
\hline Beam Code & Width $(\mathrm{cm})$ & $\mathrm{h}(\mathrm{cm})$ & $\mathrm{b}(\mathrm{cm})$ & $\begin{array}{c}\text { dimension } \\
(\mathrm{cm})\end{array}$ \\
\hline B1 & 620 & 40 & 30 & $30 / 40$ \\
B2 & 825 & 55 & 40 & $40 / 55$ \\
B3 & 550 & 35 & 25 & $25 / 35$ \\
B4 & 620 & 30 & 20 & $20 / 30$ \\
\hline
\end{tabular}

\section{Preliminary Column Design}

For column dimensions planned with a size of $60 \times 60 \mathrm{~cm}$.

Load

a) Dead Load
a. Ceramic
$=24 \mathrm{~kg} / \mathrm{m} 2$
b. Space
$3 \mathrm{~cm} \quad=53 \mathrm{~kg} / \mathrm{m} 2$
c. Light brick walls $=100 \mathrm{~kg} / \mathrm{m} 2$
d. Ceiling + hanger $=18 \mathrm{~kg} / \mathrm{m} 2$
e. $M / E$
$=25 \mathrm{~kg} / \mathrm{m} 2$
f. Waterproofing $=5 \mathrm{~kg} / \mathrm{m} 2$

b) Live Load
a. Load Floor Hotel $=250 \mathrm{~kg} / \mathrm{m} 2$

b. Load Floor Roof $\quad=100 \mathrm{~kg} / \mathrm{m} 2$

c) Earthquake Load

The combination of loading selected is the one which gives the greatest effect on the structure. The planned load combinations are shown in Table 2 below:

Table 2. Combination loading on building structures

\begin{tabular}{|c|c|c|}
\hline Nama & Kombinasi & Jenis Kombinasi \\
\hline $\begin{array}{l}\text { Combination } 1 \\
\text { Combination } 2\end{array}$ & $\begin{array}{c}1,4 \mathrm{D} \\
1,2 \mathrm{D}+1,6 \mathrm{~L}\end{array}$ & $\begin{array}{l}\text { The combination of fixed loading } \\
\text { (due to dead and alive loads) }\end{array}$ \\
\hline $\begin{array}{l}\text { Combination } 3 \\
\text { Combination } 4\end{array}$ & $\begin{array}{c}1,2 \mathrm{D}+1 \mathrm{~L}+1 \\
\mathrm{EQX} \\
1,2 \mathrm{D}+1 \mathrm{~L}-1 \\
\mathrm{EQX}\end{array}$ & $\begin{array}{l}\text { A combination of temporary loading (due to } \\
\text { dead, live and static earthquakes) }\end{array}$ \\
\hline Combination 5 & $\begin{array}{l}1,2 \mathrm{D}+1 \mathrm{~L}+1 \\
\mathrm{EQY}\end{array}$ & \\
\hline Combination 6 & $\begin{array}{c}1,2 \mathrm{D}+1 \mathrm{~L}-1 \\
\mathrm{EQY}\end{array}$ & \\
\hline Combination 7 & $\begin{array}{l}\text { 1,2 D }+1 L+1 \\
\text { RSPX }\end{array}$ & $\begin{array}{l}\text { A combination of temporary loading (due to } \\
\text { dead, live, and dynamic earthquake response }\end{array}$ \\
\hline Combination 9 & $\begin{array}{c}1,2 \mathrm{D}+1 \mathrm{~L}-1 \\
\mathrm{RSPX} \\
1,2 \mathrm{D}+1 \mathrm{~L}+1 \\
\mathrm{RSPY}\end{array}$ & spectrum) \\
\hline Combination 10 & $\begin{array}{l}1,2 \mathrm{D}+1 \mathrm{~L}-1 \\
\mathrm{RSPY}\end{array}$ & \\
\hline Combination 11 & $0,9 \mathrm{D}+1 \mathrm{EQX}$ & A combination of temporary loading (due to \\
\hline Combination 12 & $0,9 \mathrm{D}-1 \mathrm{EQX}$ & dead, live, and static earthquake) \\
\hline
\end{tabular}




\begin{tabular}{|c|c|c|}
\hline Combination 13 & $0,9 \mathrm{D}+1 \mathrm{EQY}$ & \\
\hline $\begin{array}{l}\text { Combination } 14 \\
\text { Combination } 15 \\
\text { Combination } 16\end{array}$ & $\begin{array}{c}0,9 \mathrm{D}-1 \mathrm{EQY} \\
0,9 \mathrm{D}+1 \mathrm{RSPX} \\
0,9 \mathrm{D}-1 \mathrm{RSPX}\end{array}$ & $\begin{array}{c}\text { A combination of temporary loading (due to } \\
\text { dead load, and dynamic earthquake response } \\
\text { spectrum) }\end{array}$ \\
\hline Combination 17 & $0,9 \mathrm{D}+1 \mathrm{RSPY}$ & \\
\hline Combination 18 & $0,9 \mathrm{D}-1 \mathrm{RSPY}$ & \\
\hline
\end{tabular}

\section{Modeling SAP2000}

On the results of SAP2000 analysis output there are 46 beam frames that do not meet the results due to over strange, that is, in beam B1 30/40, B2 40/55, the beam dimensions are enlarged again B1 30/60, B2 40/60

\section{Earthquake Imposition}

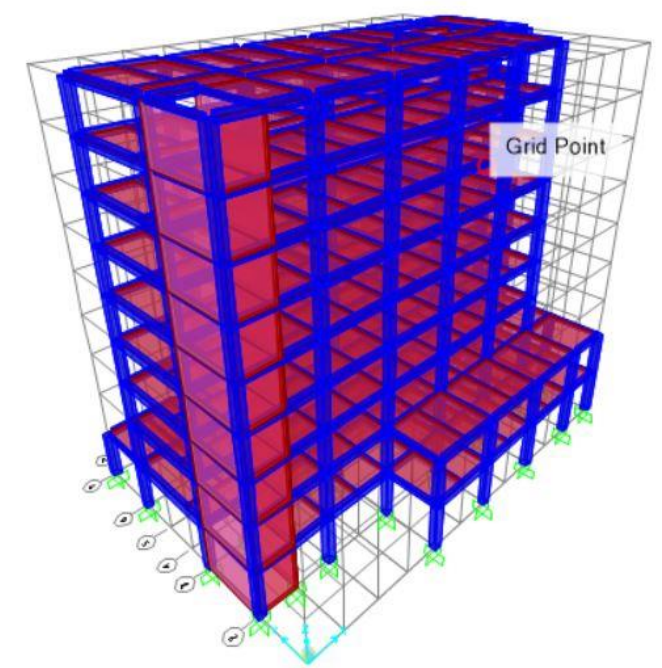

\section{Gambar 4. Modeling SAP2000}

Calculation of building structure analysis of earthquake loads refers to the Earthquake Resilience Planning Procedures for Building and Non-Building Structures (SNI 03-1726-2012). Dynamic earthquake response spectrum design is based on the response to ground acceleration (ground acceleration) results of earthquake records the design of spectrum response curve for medium soil conditions is shown in table 3 below:

Table 3 The earthquake spectrum curve value

\begin{tabular}{cccc}
\hline & \multicolumn{2}{c}{ Response Spectra Design } \\
$\mathbf{T}$ & Sa & $\mathbf{T}$ & Sa \\
\hline 0,000 & 0,250 & 1,900 & 0,201 \\
0,122 & 0,625 & 2,000 & 0,191 \\
0,610 & 0,625 & 2,100 & 0,182 \\
1,000 & 0,382 & 2,200 & 0,173 \\
1,100 & 0,347 & 2,300 & 0,166 \\
\hline
\end{tabular}




\begin{tabular}{llll}
\hline 1,200 & 0,318 & 2,400 & 0,159 \\
1,300 & 0,294 & 2,500 & 0,153 \\
1,400 & 0,273 & 2,600 & 0,147 \\
1,500 & 0,254 & 2,700 & 0,141 \\
1,600 & 0,238 & 2,800 & 0,136 \\
1,700 & 0,224 & 2,900 & 0,132 \\
1,800 & 0,212 & 3,000 & 0,127 \\
\hline
\end{tabular}

\section{Results of Beam Reinforcement Analysis with SAP2000}

Main beam is the main structure that bears the burden of the secondary structure and forwards the load to the column structure. The results of the reinforcement design calculation of the planning of the beam reinforcement are planned based on the largest moment force. Longitudinal reinforcement and shear reinforcement obtained data from concrete frame design SAP 2000 V19 code ACI 318-14. The following beam planning data:

Concrete quality $(\mathrm{K})=350 \mathrm{~kg} / \mathrm{cm} 2$

Beam dimensions $=40 / 60 \mathrm{~cm}$

Thickness of concrete blanket $=40 \mathrm{~mm}$

Table 4. The results of beam reinforcement planning using SAP2000 software

\begin{tabular}{|c|c|c|c|c|c|c|}
\hline \multirow{2}{*}{$\begin{array}{l}\text { Beam } \\
\text { Type }\end{array}$} & \multirow{2}{*}{ Dimension } & \multirow{2}{*}{ Location } & \multirow{2}{*}{ Rebars } & \multicolumn{2}{|c|}{ Rebars } & \multirow{2}{*}{ beugel } \\
\hline & & & & up & bottom & \\
\hline \multirow{2}{*}{ B1 } & \multirow{2}{*}{$300 \times 600$} & Rebars & 19 & 3 & 2 & D10-150 \\
\hline & & Rebars & 19 & 2 & 3 & D10 -200 \\
\hline \multirow{2}{*}{ B2 } & \multirow{2}{*}{$400 \times 600$} & Rebars & 19 & 5 & 3 & D10-150 \\
\hline & & Rebars & 19 & 2 & 4 & D10 -200 \\
\hline \multirow{2}{*}{ B3 } & \multirow{2}{*}{$250 \times 350$} & Rebars & 13 & 4 & 3 & D10-150 \\
\hline & & Rebars & 13 & 2 & 3 & D10 -200 \\
\hline \multirow{2}{*}{ B4 } & \multirow{2}{*}{$200 \times 300$} & Rebars & 16 & 4 & 2 & D10 -200 \\
\hline & & Rebars & 16 & 2 & 4 & D10 -200 \\
\hline
\end{tabular}

\section{Results of Column Reinforcement Analysis with SAP2000}

The planning of column reinforcement is planned based on the largest axial force from the analysis results of SAP2000 software, namely K1 column 60/60 cm at frame 590 at sap2000 on AS C-5 1st floor with column height of $400 \mathrm{~cm}$. The results of the reinforcement planning that will be used are the result of the biggest combination of loading. Longitudinal reinforcement and shear reinforcement obtained data from concrete frame design SAP 2000 V19 code ACI 318-14.

Concrete quality $(\mathrm{K})=400 \mathrm{~kg} / \mathrm{cm} 2$

Steel quality $(\mathrm{fy})=400 \mathrm{mpa}$

Column dimension $=60 / 60 \mathrm{~cm}$

Landscape height $=4.00 \mathrm{~m}$

Thickness of concrete blanket $=40 \mathrm{~mm}$

From the analysis of SAP2000 software, the results of column reinforcement are as follows:

Longitudinal Reinforcement $=14$ D 19

Beugel $=\mathrm{D} 10-150 \mathrm{~mm}$ 


\section{Calculation of Beam Reinforcement With SNI 2847-2013}

Main beam is the main structure that bears the burden of the secondary structure and forwards the load to the column structure. master beam reinforcement planning calculations are planned based on the largest moment force from the analysis results of SAP2000 software. After analyzing using SAP2000 software, the results of the internal force output with the largest load combination in the beam reinforcement calculation process.

Table 5. Results of beam reinforcement planning using calculation of SNI 2847-2013

\begin{tabular}{cccccc}
\hline $\begin{array}{c}\text { Beam } \\
\text { Type }\end{array}$ & $\begin{array}{c}\text { Dimensio } \\
\mathbf{n ~ c m}\end{array}$ & Location & Rebar & $\begin{array}{c}\text { SNI number of } \\
\text { reinforcement } \\
\text { Botto } \\
\text { m }\end{array}$ \\
\hline \multirow{2}{*}{ B1 } & \multirow{2}{*}{$300 \times 600$} & Edge & 19 & 3 & 2 \\
& & Middle & 19 & 2 & 3 \\
B2 & \multirow{2}{*}{$400 \times 600$} & Edge & 19 & 5 & 3 \\
& & Middle & 19 & 2 & 4 \\
B3 & \multirow{2}{*}{$250 \times 350$} & Edge & 13 & 4 & 3 \\
& \multirow{2}{*}{ B4 } & Middle & 13 & 2 & 3 \\
& \multirow{2}{*}{$200 \times 300$} & Edge & 16 & 4 & 2 \\
& & Middle & 16 & 2 & 4 \\
\hline
\end{tabular}

\section{Calculation of Column Reinforcement With SNI 2847-2013}

The planning of column reinforcement is planned based on the largest axial force from the analysis results of SAP2000 software, namely K1 column 60/60 cm in frame 590 in SAP2000 on AS C-5 1st floor with column height of $400 \mathrm{~cm}$. The results of the reinforcement planning that will be used are the result of the biggest combination of loading. After analyzing using SAP2000 software, the results of force output are used with the largest load combination in the column reinforcement calculation process. From the analysis of SAP2000 software, the results of column reinforcement are as follows:

Table 6. The results of column reinforcement planning use the calculation of SNI 28472013

\begin{tabular}{cccc}
\hline Type Column & Dimension cm & Rebar & $\begin{array}{c}\text { Number of } \\
\text { reinforcement }\end{array}$ \\
\hline K1 & $600 \times 600$ & 19 & 14
\end{tabular}

\section{Comparison of beam and column reinforcement analysis using SNI 2847-2013 and SAP2000 code ACI318-14}

In this study discusses the comparison of the results of reinforcement of beams and columns using analysis SAP2000 ACI 318-14 with SNI 2847-2013

\section{Beam Reinforcement}


Table 7. The results of beam reinforcement planning using SAP2000 code software $\mathrm{ACl} 318-14$

\begin{tabular}{cccccccc}
\hline $\begin{array}{c}\text { Beam } \\
\text { Type }\end{array}$ & $\begin{array}{c}\text { Dimensoni } \\
\mathbf{c m}\end{array}$ & Location & Rebar & $\begin{array}{c}\text { SAP number } \\
\text { of } \\
\text { reinforcement } \\
\text { Botto } \\
\text { m }\end{array}$ & \multicolumn{2}{c}{$\begin{array}{c}\text { SNI number } \\
\text { of } \\
\text { reinforcement }\end{array}$} \\
\hline \multirow{2}{*}{ B1 } & \multirow{2}{*}{$300 \times 600$} & Edge & 19 & 3 & 2 & 3 & bottom \\
\hline \multirow{2}{*}{ B2 } & \multirow{2}{*}{$400 \times 600$} & Middle & 19 & 2 & 3 & 2 & 3 \\
& & Edge & 19 & 5 & 3 & 6 & 3 \\
B3 & $250 \times 350$ & Edddle & 19 & 2 & 4 & 2 & 3 \\
& & Middle & 13 & 4 & 3 & 4 & 3 \\
B4 & \multirow{2}{*}{$200 \times 300$} & Edge & 16 & 2 & 3 & 2 & 3 \\
& & Middle & 16 & 2 & 4 & 2 & 4 \\
\hline
\end{tabular}

From the table above, the percentage difference between the results of the reinforcement of the structure of the beam analysis is analyzed using sap2000 code ACI318-14 and SNI 2847-2013.

The number of reinforcement using SAP2000 code ACI318-14 = 36 pieces The number of reinforcement using SNI 2847-2013=37 pieces

$\%$ Difference reinforcement $=$ difference reinforcement $/$ number of beams

$$
\begin{aligned}
& =1 / 6 \\
& =0.17 \%
\end{aligned}
$$

\section{Column Reinforcement}

The amount of column reinforcement obtained from the analysis of sap2000 code $\mathrm{ACl} 318-14$ and calculation of SNI 2847-2013 is the same as the $60 \times 60 \mathrm{~cm}$ column with the reinforcement of 14 D 19

\section{CONCLUSION}

In plimelinary beam designs with sizes B1 $30 / 40 \mathrm{~cm}$ and B2 $40 / 55 \mathrm{~cm}$ unable to withstand the load on the structure (over strange), the beam dimensions are enlarged to be B1 30/60 cm and B2 $40 / 60 \mathrm{~cm}$. In the results of SAP2000 analysis output after the dimensions of the beam are enlarged there are no frames that are over strange and meet the strength of the structure.

From the beam analysis planning on bending reinforcement using SNI 03-28472013 concrete reinforcement regulation and using SAP2000 code ACI318-14 software analysis, the number of reinforcement obtained is more using SNI 03 - 2847 - 2013 concrete reinforcement regulation compared to using SAP2000 code analysis software $\mathrm{ACl} 318-14$ the amount of reinforcement use has a difference of $0.17 \%$.

From the planning of column analysis on bending reinforcement using SNI 03-2847-2013 concrete reinforcement regulations and using SAP2000 code ACI318-14 software analysis, the same amount of reinforcement is obtained between calculations using $\mathrm{SNI}$ 03-2847-2013 concrete reinforcement regulations and using SAP2000 code ACI 318-14. 


\section{REFERENCES}

Asroni, Ali. 2010. Reinforced Beams and Concrete Plates. Graha Science. Yogyakarta.

Chu-Kia Wang, Salmon Charles G. 1993. Reinforced Concrete Design. Erlangga. Jakarta

Hambali, Achmad. 2016. "Comparison of Earthquake Resistant Structure Planning Based on SNI 03-1726-2002 and SNI 03-1726-2012 Case Study Malioboro City Yogyakarta Apartments". Thesis. Department of Civil Engineering, Faculty of Engineering, Muhammadiyah University, Yogyakarta. Yogyakarta

Karna, I Putu Bagus Brahmantya. 2015. "Comparison of Building Structure Behavior Without And With Reinforced Concrete Sliding Walls". Thesis. Jurusan Civil Engineering, Faculty of Engineering, Udayana University. Denpasar

Lukmansa, Indra. 2015. "Comparative Study of Steel Structure Planning Using Ordinary Profiles and Kastela Profiles in the PGN Building Project in Surabaya". Thesis. Department of Civil Engineering, Faculty of Engineering, University 17 August. Surabaya

Mulyo, A. 2004. Introduction to Earth Sciences. Loyal Heritage. Bandung.

Muto, K. dan Wira. 1987. Analysis of the Design of Earthquake Resistant Buildings. Erlangga. Jakarta.

National Standardization Agency (2012). The Procedure for Designing Earthquake Resilience for Buildings (SNI 03-1726:2012., Indonesian National Standards. Jakarta

National Standardization Agency (2013). Structural Concrete Arrangements For Buildings (SNI 2847:2013 Indonesian National Standards. Jakarta

National Standardization Agency (2013). Minimum Load For Building Planning And Other Structures (SNI 1727:2013). Indonesian National Standards. Jakarta

Nasution, Amrinsyah. 2009. Analisis dan Desain Struktur Beton Bertulang. ITB. Bandung.

Prawirodikromo, W. 2012. Seismology Engineering \& Earthquake Engineering. Student Library. Yogyakarta.

Servie O, Dapas, Ronny Pandalake. 2018. "Planning of Reinforced Concrete Building Structures with Special Moment Resistant Frame Systems". Thesis. Department of Civil Engineering, Faculty of Engineering, Sam Ratulangi University, Manado. Manado

Sugiyono. (2011). Educational Research Methods Quantitative, qualitative and R\&D approaches. Alfabeta. Bandung

Tjokrodimuljo, K. 1996. Concrete Technology. Civil Engineering Department, Faculty of Engineering, Gadjah Mada University. Yogyakarta

Wuryati, S. \& Candra, R. 2001. Concrete Technology. Kansius. Yogyakarta

YudhaPanata, Agus. 2018. "Comparative Analysis of Round and Square Columns Against Performance of Reinforced Concrete Buildings Due to Earthquake Loads Case Study of BKPSDM Building Padang Panjang City". Thesis. Civil Engineering Department, Faculty of Engineering, Padang Institute of Technology. Padang 